Article

\title{
Does the Homogeneous City Belong to the Past?
}

\author{
Valentin Bourdon \\ Construction and Conservation Laboratory, Swiss Federal Institute of Technology Lausanne, 1015 Lausanne, Switzerland; \\ E-Mail: valentin.bourdon@epfl.ch
}

Submitted: 31 March 2019 | Accepted: 19 July 2019 | Published: 30 September 2019

\begin{abstract}
As the case of Paris embodies, a whole culture of the European city has built its identity and organized the collective life of its inhabitants on the idea of homogeneity. The homogeneous city has thus significantly contributed to the collective self-representation through housing architecture. The strong degree of homogeneity of the nineteenth-century European city undoubtedly represents one of the most vivid examples of an architectural self-celebrating collective moment. This singular urban coherence is one of the few attributes of the traditional city spared by the Avant-gardes in the early twentieth century, for its ability to absorb a large number of variations without compromising the expression of continuity. A careful reading of their three main housing models - the Siedlung, the Hof and the Garden City-could confirm such a perspective, as do Existenzminimum standards. This long-standing tradition now seems to have been broken, since the homogeneous city is no longer considered as a current operating principle for urban planning. In order to understand-and perhaps overcome - the reasons for such resistance to one of the prime elements of European urban history, this article proposes to review its evolution over the last two centuries, focusing on the importance given to housing in the establishment, and the criticism and potential renegotiation of homogeneity as a malleable and latent principle.
\end{abstract}

\section{Keywords}

architecture; European city; housing; urban theory; urban homogeneity

\section{Issue}

This article is part of the issue "Housing Builds Cities", edited by Luca Ortelli (École Polytechnique Fédérale de Lausanne, Switzerland), Chiara Monterumisi (École Polytechnique Fédérale de Lausanne, Switzerland) and Alessandro Porotto (École Polytechnique Fédérale de Lausanne, Switzerland).

(C) 2019 by the author; licensee Cogitatio (Lisbon, Portugal). This article is licensed under a Creative Commons Attribution 4.0 International License (CC BY).

\section{Introduction}

The collective substance of the European city cannot be reduced to its public space and its monuments. It also emerges from the private sphere: the domestic one, that of the dwelling (Rossi, 1966, pp. 71, 127). As a primary urban artefact, housing has the singular capacity of embodying the collective consciousness of belonging to the city. This capacity comes from the sheer quantity of housing, and the perception of repetition, in spite of a variation of its qualities. Housing directly participates in the urban fact thanks to the power of the ordinary. Common features vary in their extent, intensity and motivations. They can be observed at the scale of a neighbourhood, or in the wider contexts of urbanization; they can occur in a circumstantial manner or an authoritarian one.
In order to grasp its architectural meanings, it is necessary to understand the origins and the political value of the ordinary. Also, the cohesion we are examining is not limited to a specific language, style or function. Urban homogeneity is rather considered here as the critical, sensitive and transversal identification of common denominators in housing phenomena or policies. The notion of homogeneity has long been used in architectural and urban discourse for quantitative or sociological aspects, mainly as an adjective, but it has never been observed as a large and multifaceted theoretical issue regarding housing and domesticity. Instead of interpreting it as a strictly measurable spatial value (Maïzia, 1999), or as a social mapping tool (Bailly \& Beaudry, 1976), we propose to focus on its architectural and normative aspects, which have not yet been fully considered. This 
step is a prerequisite for the up-to-date assessment of homogeneity as an architectural principle, which the last decades seem to have (definitively?) associated with negative connotations.

Compared to an architectural production largely focused on originality and demarcation, the principle of homogeneity could appear anachronistic. When applied to the contemporary city, the notions of 'coherence' or 'environment' are used with a more positive connotation to escape the monotony to which homogeneity is commonly affiliated. However, the usual association of homogeneity with uniformity appears not only questionable, but also limiting. While uniformity induces the absence of variation and conformity to a reference model, homogeneity admits the possibility of similarities, thereby closely relating to the notion of 'type' already introduced in the theory of architecture (Quatremère de Quincy, 1788-1825, pp. 543-545). Discussing homogeneity sometimes evokes rhetorical postulates, which can be difficult to evaluate. Nevertheless, it opens the door to richer latitudes than strict unity, and to a more precise framework than that given by coherence, or even harmony. Although malleable and inaccurate, it seems legitimate to recognize the importance of this principle. It impacts systematically on the history of the city, according to different time periods, and in a cumulative continuity that architectural culture should register.

To analyse this question in-depth and go beyond an ambiguous or even traumatic apprehension, we propose to identify and methodically confront four main architectural periods at regular intervals of 50 years. These four historical periods are intended to highlight the affirmation and the crisis of 'the homogeneous city' as a driving principle for habitat construction. Each theoretical marker mobilizes housing as an ideal priority in enabling the assertion of a collective character in urban planning. First, the completion of the Parisian Avenue de l'Opéra in 1879 is one of the strongest affirmations of a figural homogeneity used in shaping the city through housing. Half a century later, in 1929, the second CIAM (Congrès Internationaux d'Architecture Moderne) in Frankfurt embodies the vision of modern progress with a universal vocation by proposing an egalitarian and normative conception of the city. Existenzminimum then leads to a renewed homogeneity defined by the slight variations in standard residential units (Mohr, 2011). In 1979, the keen interest in the completion of the Hautes-Formes social housing development in Paris is an important turning point in the architectural appropriation of the homogeneous city. Homogeneity as a theme is then categorically refocused on a more conciliatory interpretation of urban continuity. Finally, looking to the present and the near future, just one decade separates us from the next period proposed by this sequence. Due to recent changes in building function, energy consumption and architectural composition, the next few years could be decisive for the evolution and evaluation of the homogeneous city as a design tool.

\section{1879 and the Bourgeois Celebration}

The city of the nineteenth century is exemplary in its ability to give form to urban homogeneity. The case of Paris is particularly significant (Loyer, 1987, pp. 232-233). Beyond the city, Napoleon first initiates a deep restructuring on a territorial scale. The beginning of the century is then marked by an unprecedented policy of large construction sites, driven by an ambition of identity. Infrastructure and public facilities-especially schoolsare primarily mobilized to support the project of national homogeneity. Between 1831 and 1881, successive laws consolidate the obligatory use of French; language is considered an important driver of unification. Afterwards, it is on an urban scale, and through 'architectural language', that homogeneity becomes a project. Here again, centralized authority greatly contributes to the coherence of many structural spatial decisions. In urban areas, the state focuses mainly on the network of monuments and on the homogeneous treatment of public spaces (Alphand, 1867). In the face of state interventionism, the equally powerful presence of economic forces strongly contributes to giving Paris a united aspect. As César Daly $(1864$, p. 9) states in the introduction to L'architecture Privée au XIX Siècle: "a favourably inspired administration set out, by immense construction works, to establish a missing harmony between the great Parisian city and the needs of its inhabitants", and he specifies, "this great effort of the administration has led speculators and architects to make a similar effort". Also, the recognizable character of the nineteenth century city comes not only from a directive embellishment, but also from the visible outcomes of real estate speculation generated by the housing market. The immeuble de rapport (block of flats) and, in particular, its Haussmannian variations, are the main tool of a homogeneous formalization of the habitat, and of the city (Loyer, 1987, p. 232). The homogeneity of the 'City of Lights' comes thus from the private sphere, through housing.

The completion of the Avenue de l'Opéra in 1879 is one of the most evident gestures joining public and private interests by adopting a form of urban homogeneity. The coherent perception of the whole is mainly guaranteed by enforcing guiding projections dictated by the political power, and to which architects must comply (Eleb, 1991, p. 286). This architecture réglementaire is also supported by the complicity of various Beaux-Arts architects adhering to a common work. In support of academic tradition, the legislative effort is then able to maintain homogeneity, without requiring the duplication of any of the buildings. One of the strengths of the Haussmannian project is to "make one forget the incoherence of successive actions, the divergence of the projects or that of typologies, to bring out the city as a whole; the extreme diversity of its parts only reinforces the overall coherence" (Loyer, 1987, p. 232). Henceforth, housing is no longer just the basic raw material of the city, as defined by Vitruvius (1673, p. 15), but strongly perceived as real 

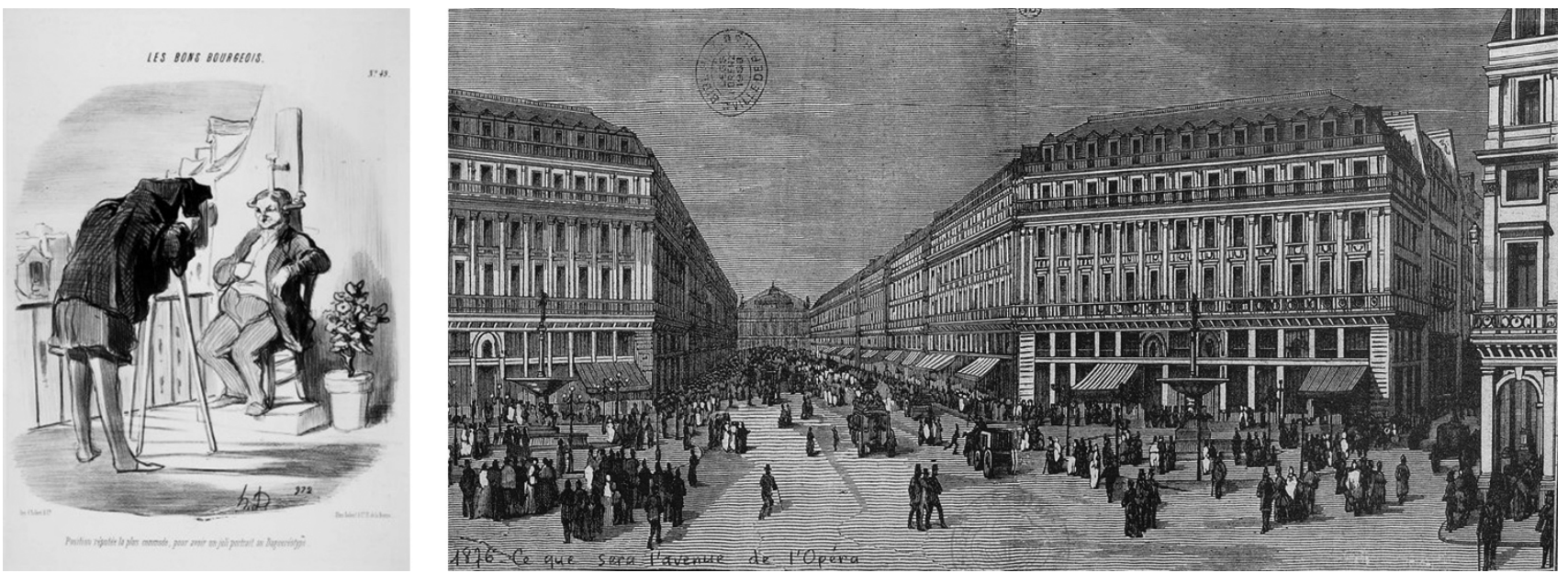

Figure 1. Social representations. From left to right: The lithography of Honoré Daumier (1808-1879), with the caption

"The good bourgeois-Position reputed most convenient to have a nice portrait in Daguerreotype", published in a satirical newspaper in 1847; the engraving previewing the Avenue de l'Opéra in 1876. Sources: Daumier (1847) and "Paris. Avenue de l’Opéra, percement et projets" (1876).

design material. Dwellings are at the service of an urban intention: the celebration of the homogeneous city. In return, homogeneity itself showcases the inhabited material of the city, even more than its own monumentswhich appear almost interchangeable, even subsidiary. Between 'the administration' and 'the speculators' mentioned by César Daly, 'the architects' could propose an alternative that is more cultural, and closer to the idea of common good: that of collective self-representation. To satisfy its expectations in terms of self-representation, the assertive bourgeoisie does not wait for the inauguration of the Garnier Opera, considered as the symbolic place of all the representations, both scenic and social. During the mid-nineteenth century, the Parisian success of the daguerreotype is a significant sign of the bourgeois quest for self-representation (Figure 1).

Twenty years after the development of this revolutionary photographic process, Charles Baudelaire (1868, p. 259) criticizes its popular use in these words: "The filthy society rushed like a single Narcissus to contemplate its trivial image on the metal". To use his words, the Haussmannian project could also respond to the bourgeois need for contemplation, in stone, of its own figuration. Over time, urban character, as a 'common good', can finally go beyond the limits of its social origin, and offer the enlarged city a renewed image of its identity signs. This is the observation made by François Loyer (1987, p. 330) when he notes that, in the 1860s, "the standardization will even cross the technical barrier of materials...and one will find poorer versions of great bourgeois buildings in Ménilmontant, even though they are identical in profile and size". The apogee of an eminent, collective and homogeneous urban culture, able to go beyond the social fragmentations of the city, faces violent criticism from 1880 onwards. As noted by Monique Eleb (1991, p. 294), the testimonies of Eugène Viollet-leDuc and Charles Garnier are particularly representative of a new generation of architects condemning uniformity and monotony, and who sought a deregulated eclecticism. Eugène Viollet-le-Duc (1872, p. 305) regrets the effacement of the individual, of his footprint and of his personality; Charles Garnier (1892, p. 811 ) is saddened by the long perspectives of regular facades with repeated ornaments, and also deplores the loss of any personal physiognomy. It is surprising to observe that such arguments continue to be used by the detractors of architectural or urban homogeneity, especially when referring to projects of modernist influence. The remarkable relevance of the debate concerning the homogeneous city at the end of the nineteenth century is an eloquent sign of its periodic character.

\section{1929 and the Modern Approval}

Associated with the second CIAM, the year 1929 represents an historic and theoretical landmark for the formulation of an architectural vision of homogeneity, based on housing. Following the pre-modern experiments marked by industrialization, and contrary to many categorical breaks with academicism, the "Declaration of La Sarraz" (1928), then the Existenzminimum (1929), affirm once again homogeneity as an essential tool for the development of modern precepts, and the achievement of their goals. It is no longer the expression of a bourgeois celebration, but a powerful emancipatory force of the working class, marked by the production of dwellings that are conceived and carried out for the greatest number. The second CIAM sets as an objective a unitary and massive progress, commensurate with the progress of industrial development. Even though it embraces a radically different ideology, it continues the project of the previous century by adapting architecture to the technological evolution that defines its time. Moreover, the words used by Loyer (1987, p. 232) to describe the 
transformation of Paris in the nineteenth century are also valid when talking about the modern Avant-garde: "rather than deny the industrial society (or even to ignore it), it [the transformation of Paris] strives to domesticate its power and subject it to a more global cultural vision". The "obligation to create, in all fields, a new state of equilibrium" is advanced in these terms at La Sarraz and reiterated the following year by Le Corbusier (Steinmann, 1979, pp. 12, 62). This perspective of unity, which he considers as the main goal of each revolution, is linked very early on to the field of housing. Even before 1929 , the balance between uniformity and homogeneity related to housing is particularly discussed in the German debate. Ludwig Hilberseimer (1927, p. 100) explicitly considers housing as a privileged material in the building of the city, after having radically mobilized it in its homogeneous - even uniform - project of the Vertical City (1924). One step further, the first two CIAM also consider the dwelling as a laboratory of innovations available for other uses (Steinmann, 1979, p. 17). These possibilities of transfers and variations deviate from strict uniformity and lead to more flexible attitudes. Residential architecture appears as the origin and the privileged support of a homogeneity that exceeds the functional criterion. Starting from housing, the second CIAM in Frankfurt establishes the constructive proposal of rationalist architecture, recognizable by the radicalism of the structural open frame, and the evocative power of the uniform coating of plaster (Figure 2). Instead of maintaining continuities with the existing city, the Existenzminimum imposes the new standards of its own homogeneity. A homogeneity that surpasses the scale of the city and echoes the emergence of an international style.

The homogeneity defended by the Existenzminimum is not devoid of authority. In its demonstrative dimensions, the 1929 CIAM embodies the affirmation of a clear direction, in which a group of non-unitary but unified architects proposes to drive architectural production. The tone of its programmatic and constructive syntheses is mainly prescriptive. Its typological repertoire is equally normative. The associated exhibition entitled "Homes for Minimum Incomes" presents the radical representation of housing as standard floor plans (International Kongresse für Neues Bauen, 1930). Housing is presented in a deeply interventionist way, in a detailed search for economic and even moral optimization which is evident in the similarities between the floor plans. As presented by Victor Bourgeois (Steinmann, 1979, p. 34), the minimum house program indicates a level of unmatched anticipation in the history of architecture regarding habitat. It goes so far as to dissuade the hanging of paintings or photographs on the walls because they collect dust and prevent rest, or to consider old objects and the attic as sources of unhealthy disorder (Steinmann, 1979, pp. 54-55). The optimization of the minimum housing unit is not limited to its constructive aspects. It invades all aspects of housing in a quite authoritarian manner, even its most intimate features. Under the guise of adapting architecture to technical changes, the modern enthusiasm strongly contributes to promoting and increasing their impact in the habitat. Progress, as a leitmotiv, then justifies any normative distancing with the past (Figure 3).

Mainly dedicated to the affirmation of the fundamental breaks carried out by modernity, the second CIAM (like the first one) remains very discreet about the inexplicit continuities it pursues from the nineteenth to the twentieth century. To review certain similar trajectories hitherto too often excluded, such as the terrain of vernacular production, it is useful to highlight new hypotheses concerning the origins and the future of modern homogeneity. The dwelling unit of the Existenzminimum is

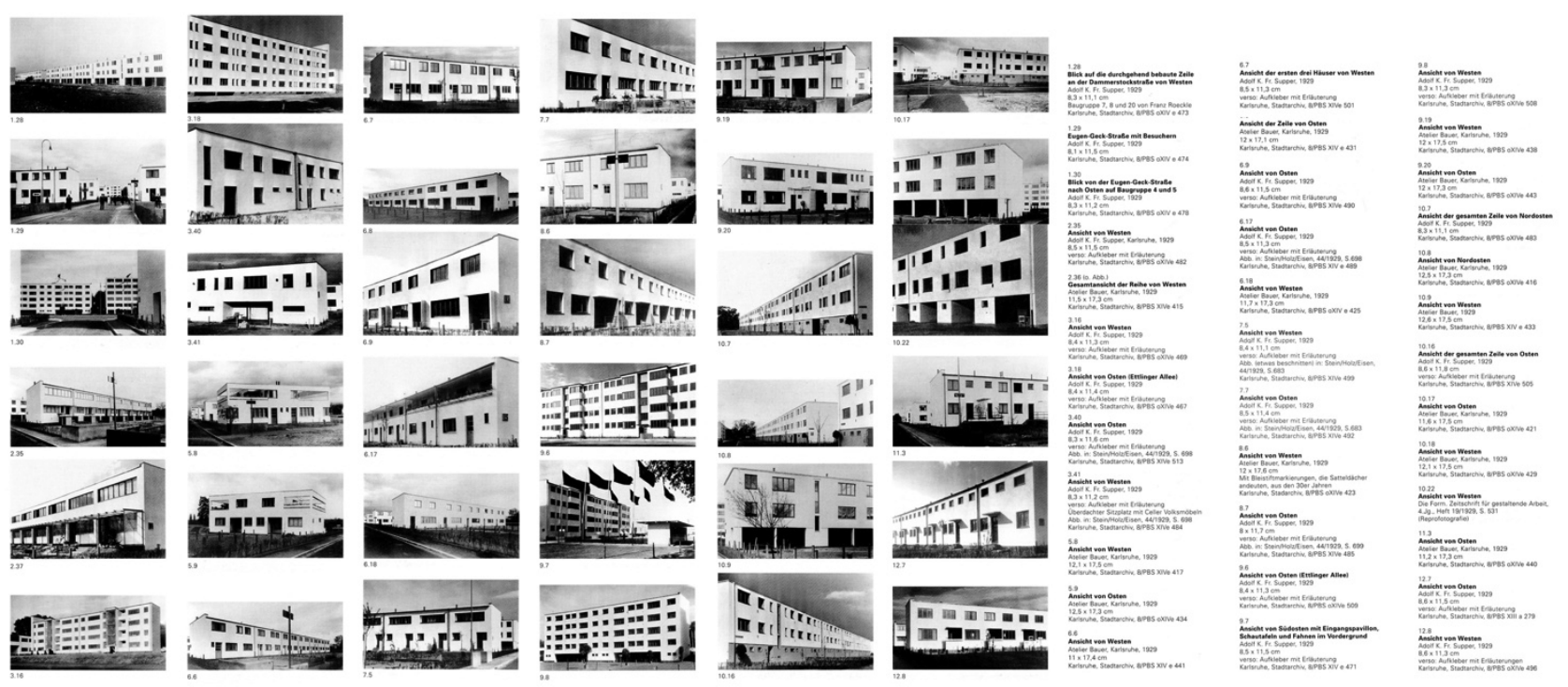

Figure 2. Extracts from the "Katalog" presented in the appendix of Neues Bauen der 20er jahre, Gropius, Haesler, Schwitters und die Dammerstocksiedlung in Karlsruhe 1929. Source: Franzen (1997). 

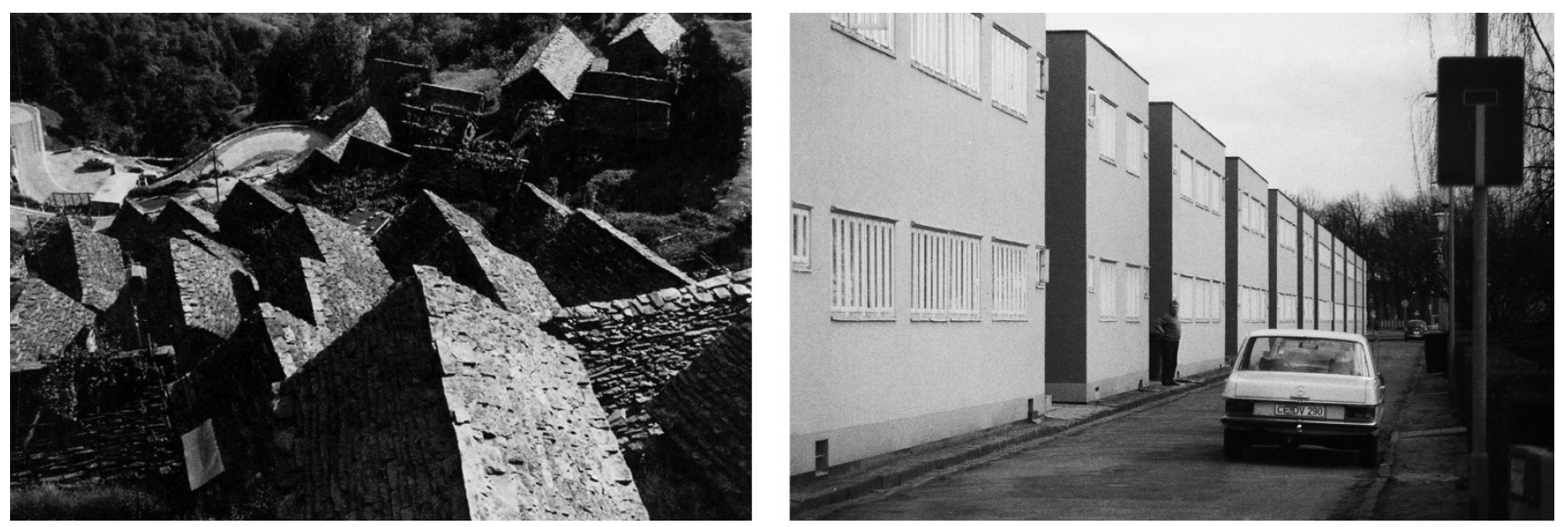

Figure 3. The visible homogeneity from vernacular architecture to the statement of modernity. From left to right: The traditional village of Brontallo, Switzerland; the Blumläger Feld Siedlung designed by Otto Haesler in 1930 in Celle, Germany. Note: Both photographed in the late 1970s. Sources: Rossi, Consolascio and Bosshard (1979) and Wagner (1979).

destined for a traditional family unit, which explains the low variation of its spatial features, similarly to vernacular habitat. Although the scale of the collective building is widely discussed at the Frankfurt Congress, the onefamily-house remains an essential reference unit. A significant proportion of the repertoire does not question the formal recognition of the elemental social unit in its urban perception-perhaps one of the main distinctive signs of the vernacular habitat. The program described by Victor Bourgeois (Steinmann, 1979, p. 55) even amplifies this perception by associating private gardens with housing. Their partial use for domestic agriculture is reminiscent of a traditional rural relationship between the home and its surroundings, which is adapted to modern urbanity. At Römerstadt-the Siedlung barely completed in 1929 and already the showcase of the second CIAM 2-some open spaces accessible to all can also be seen as the reinterpretation of the traditional common lands. Kenneth Frampton (1980, p. 137) introduces this possibility by linking some exterior spaces of May's hous- ing settlement to those of traditional villages: the Anger. Such analogies could link the production of committed architects with a careful examination of the qualities of popular habitat. They encourage a less mechanical interpretation often associated with the nascent modernity, and emphasize the already systematic character of traditional constructions. The vernacular habitat itself already expresses a certain standardisation, as described by its typological variations. This is undoubtedly one of the main lessons of La Costruzione del Territorio del Cantone Ticino (Rossi, 1979).

It is especially noteworthy to observe that the measurements of the houses in Brontallo are directly related to the size of the wooden beams used in local construction. The normative character of the vernacular habitat derives from the bottom-up specificities considered over a long period of time. It builds on the constraints and availability of local features rather than universal needs, through the continuous transmission of knowledge. The Existenzminimum is a sudden top-down exercise of schol-
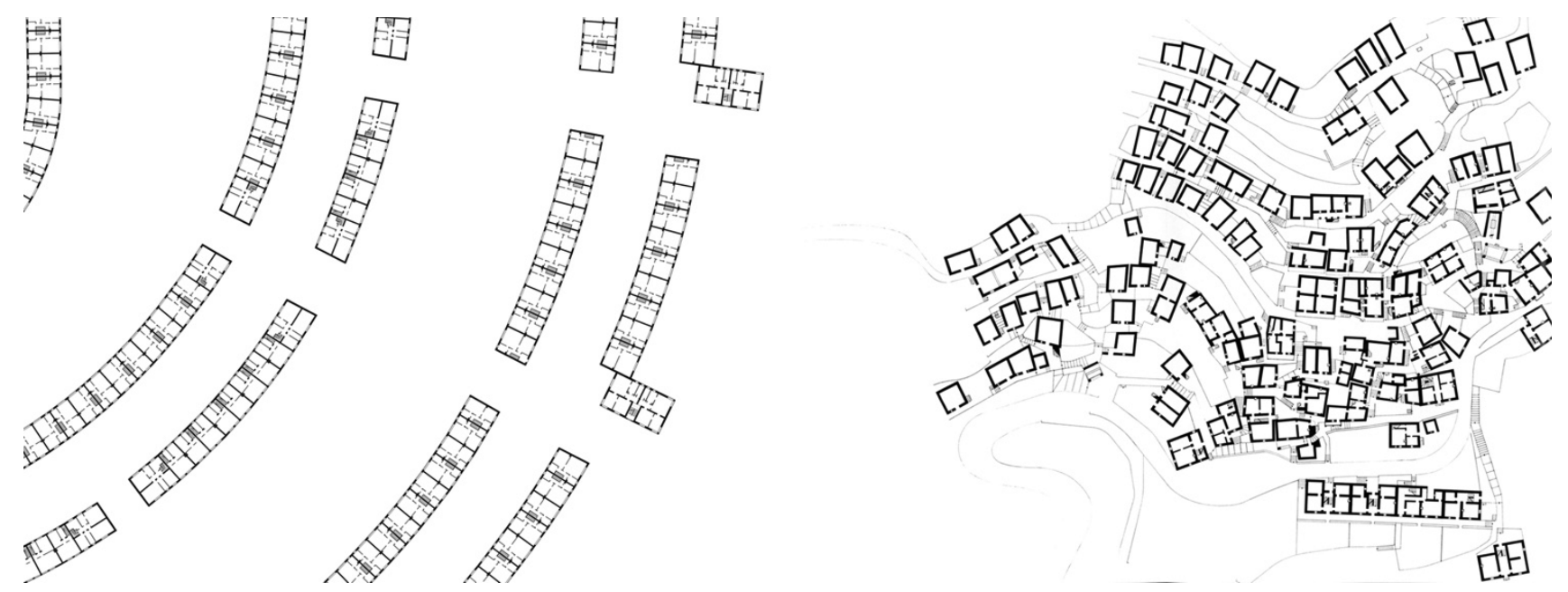

Figure 4. The typological homogeneity from vernacular architecture to the statement of modernity. From left to right: Römerstadt typological assembly from Logement de Masse: Vienne et Francfort; Brontallo typological assembly plan from La Costruzione del Territorio del Cantone Ticino. Sources: Porotto (2018) and Rossi et al. (1979). 
arly optimization, defined a priori. However, it proposes a comparable typological inventory. The homogeneous graphic representation of its types shows their variations, with a similar intensity to that of the drawings produced by Aldo Rossi and his pedagogical team at ETH Zurich (Rossi et al., 1979) for the study of the Ticino territory (Figure 4). The Existenzminimum confirms a pre-existing capacity of residential architecture: that of absorbing a large number of variations without compromising the expression of continuity. More than the local circumstances themselves, the variations result from the sensitivity of the authors, from their capacity to adapt the form of the models to local constraints. The scholarly appropriation of such a theme introduces typology as the art of variation, and the manifest adherence to the principle of the homogeneous city as a new space of architectural invention.

As soon as CIAM architects decide to renew the principle of homogeneity in modernity, they immediately raise the question of its intensity, its industrial and/or architectural variations and its authorship. The split described by Jacques Gubler (1988, pp. 152-155) at La Sarraz in 1928 introduces crucial uncertainties in the modern definition of the homogeneous city. In spite of the insistence of Le Corbusier when he tries to institute the principle of standardization in the first program of the Swiss CIAM, his fellow conferees "consider it inappropriate to codify the plastic grammar of the new architecture, as well as to confer universal value on particular devices, since their implementation is based more on the architect's individual language than on a strict technical necessity" (Gubler, 1988, pp. 154-155). Architectural inventiveness is therefore observed in the light of a threatening homogeneity. And the threat is twofold. On the one hand, the excessive standardization of construction would be tantamount to "nipping architecture in the bud", according to the precautions formulated by Le Corbusier himself (Steinmann, 1979, p. 18). On the other hand, the excessive authority of the architectural model appears in 1929 as a possible setback of an initially laudable intention.

\section{1979 and the Traumas of the Masses}

The trajectory of the progressive homogeneity, initiated with the Existenzminimum, reaches its critical threshold in France with the controversial figure of the grand ensemble. The architecture of the second post-war period to address the issue of mass housing continues to exert a real trauma on a large part of popular urban culture. The mistrust of social formalism-as the simultaneous or consecutive product of public interventionism and capitalist economy-is first expressed in the reactions of a counterculture that began to emerge in the 1960s. In parallel, a critical re-reading of the modern movement develops within the field of architecture itself (Aureli, 2013, p. 12). The trauma of the grands ensembles then spreads to public opinion: that of the masses, to whom the urban homogeneity of modernity was supposed to be addressed. The non-identification of individual dwellings in buildings is associated with the image of an oppressive administrative egalitarianism, condemning residents to anonymity. The perception of a mechanical repetition of the constructed forms is amplified by the programmatic homogeneity introduced by zoning. Initially thought of as an enhancing planning tool, mono-functionality is then confronted with the social and economic reality of these ensembles. The popular criticism of urban monotony is
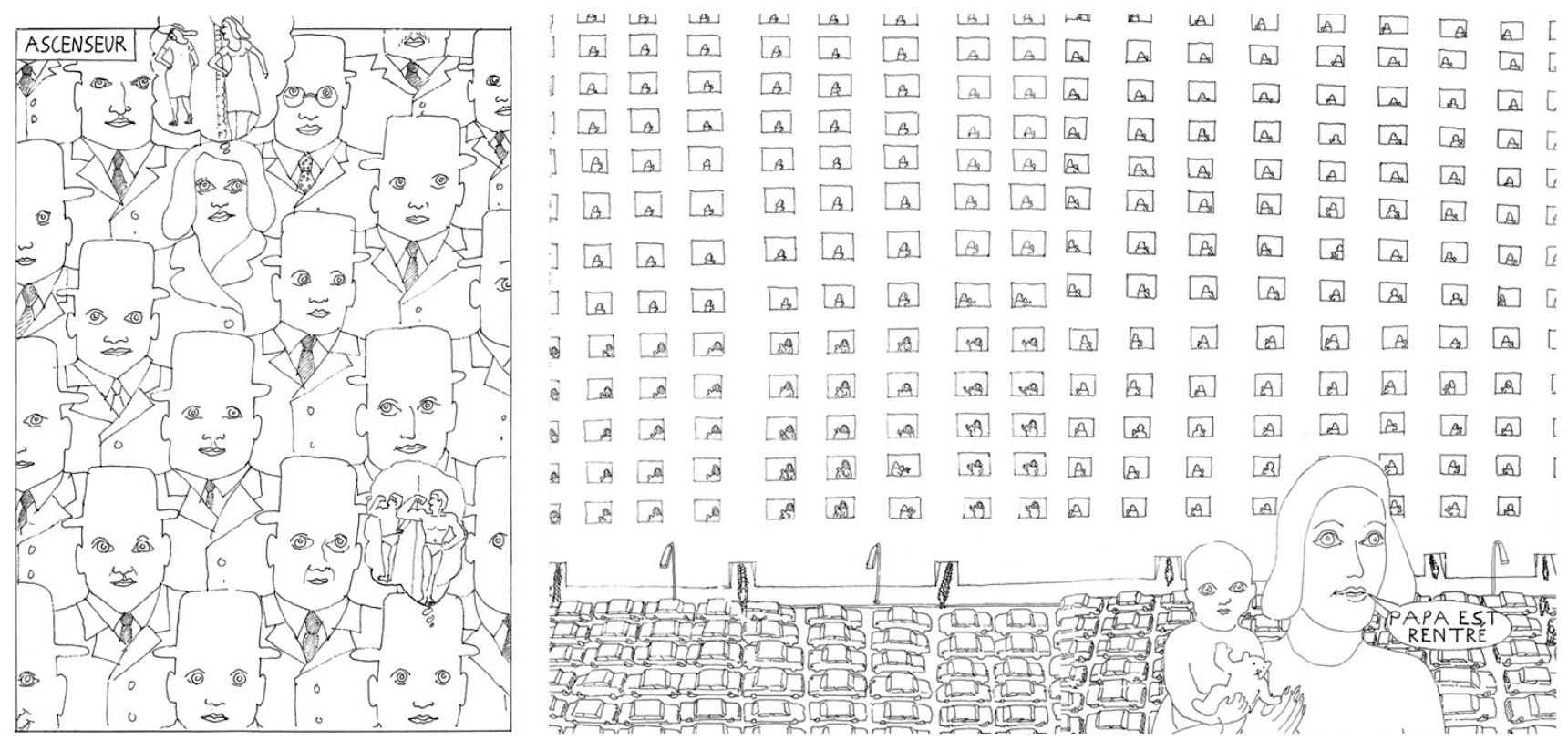

Figure 5. The Soft-City dystopia imagined by Hariton Pushwagner between 1969 and 1975, a sharp criticism of modern uniformity, particularly explicit in its architectural aspects. Source: Pushwagner (2017). 

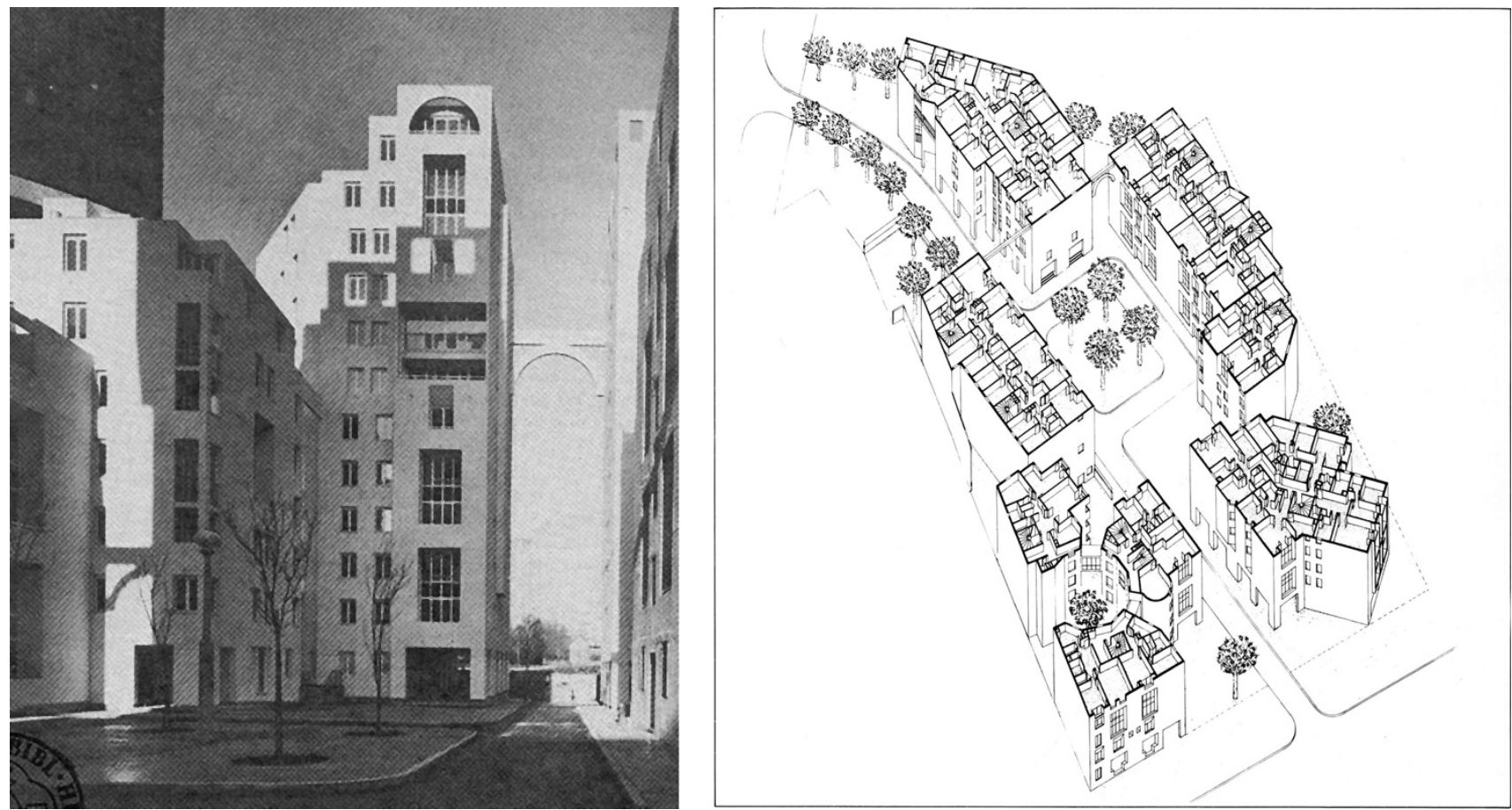

Figure 6. The Rue des Hautes-Formes. From left to right: Photograph from 1979, after the completion of the operation carried out by Giorgia Benamo and Christian De Portzamparc; general axonometry of the operation. Source: "Paris, rue des Hautes-Formes. Dossier iconographique" (1979) and Portzamparc (1984).

added to that of an alienation of individuality; the rationalist path imposed by the crane does not admit the picturesque accidents that the unity of the traditional city generates. Pushed to the limit of its semantic field by an excess of rationalist, 'homogeneity' shifts towards 'uniformity'. The mix-up is so powerful that it persists today. It symbolically takes shape in the constructed objects, which endorse negative connotations, but also in the architectural principles that determined them (Figure 5). Reduced to the idea of uniformity and repetition, homogeneity is considered a failure, and becomes a scapegoat for modernity.

The completion of the Hautes-Formes in Paris in 1979 marked an important turning point in the perception of the homogeneous city. "After two decades of functionalist cynicism and brutality", Eleb and Cohen (2000, p. 159) consider this project of 210 social housing units as the final moment of the grands ensembles episode. The enthusiasm it aroused-beyond the Parisian debate-is the sign of a broad shift towards the traditional city, in its contained scale and its diversified nature (Figure 6). The houses designed by Giorgia Benamo and Christian De Portzamparc have the particularity to redefining their own urban space, closely related to the dense city (French, 2008, p. 168). They defy orthogonality, abandon symmetry and opt for the multitude: "each apartment has a particular plan (one hundred variants are proposed for eighteen types of housing), linked to its position in the building, its orientations, its views" (Eleb, Cohen, \& Martinelli, 2000, p. 159). The typological tools elaborated by modern Avant-gardes in order to maintain a contained variety are no longer sufficient to satisfy the popular and political expectation of differences. Also in 1979, the Quartier de L'horloge simulates the absence of plot division in the heart of Paris. Its architect Jean-Claude Bernard seeks to propose "chance variations within a general harmony" (Lucan, 1992 p. 183) thanks to the expressive and volumetric heterogeneity of its facades. These emblematic achievements do not reject the homogeneous city, but divert it from its functionalist delineation, in search of more diffuse, more cultural, but also more ambiguous new formalizations.

It is also between 1978 and 1980 that a series of Zones d'Aménagement Concerté was launched in Paris. Jacques Lucan (1992, pp. 184-185) notes their strong tendency for architectural heterogeneity. The following generations of Parisian ZACs confirm this trend, leading Jacques Lucan (2012, pp. 65-66) to observe, twenty years later, the continued demarcation of one-off operations. Paradoxically, the degree of variation in their housing plans is similar to that of the Existenzminimum repertoire: "The programs are indeed 'generic', very similar from one client to another, and the types of housing, which are also 'generic', are determined by 'market demands"' (Lucan, 2012, pp. 65-66). In reaction, he notes "an exacerbation of the distinctive features of the operations, both in terms of form and materials used... with often vivid chromatic choices-whereas a city like Paris is essentially 'monochrome"' (Lucan, 2012, p. 66). Jacques Lucan's comments reveal the post-traumatic ambiguity that characterizes such an architectural production. Its exacerbated figurative diversity actually conceals a per- 
sistent substantial homogeneity, from which it is difficult to escape. This homogeneity is linked to the reality of the construction process (Périphériques Architectes, 2007, p. 25) and to housing as a standardized product. An unavowed form of homogeneity persists, in the shadow of agitated differences. These expressions of diversity are often so systematic that they also become generic, as a uniform expression of particularities.

\section{2029 or the Promises of Undifferentiation}

Among the trends that emerge during the next ten years, there is one in particular that offers the homogeneous city new perspectives: that of no differentiation. Even though there is a clear popular attachment to architectural diversity, it is striking to observe how certain cultural traits have easily become widespread in recent decades, such as white interiors, standardized furniture or smartphones. Acceptance of homogeneity is extremely variable, and reflects a continuous adjustment between individual and collective selfrepresentation. It concerns not only the physical characteristics of everyday spaces and objects, but also the understanding of their status, their emotional value, and their representational codes. Beyond the architecture field, the sudden development of social networks testifies to the success of such a homogeneous formalization of (self-)represented entities. The most popular have the striking peculiarity of presenting one person or a multina- tional company in the same way, at least in appearance. Friendships, family, leisure, culture, media, associations, consumption and institutions share the same mode of self-representation, in a fictitious but formally homogeneous indifference. Alain Guiheux (2017, pp. 79-90) identifies the architectural equivalent of such a level of no differentiation as the grand espace commun. By absorbing the traditional spatial and social frameworks, it defines a decompartmentalized, unitary and ubiquitous life. Also, the blurring of representative boundaries between public and private spheres, work life and life outside work, the individual and networking, could affect the popular acceptance of a new figurative homogeneity. Considering the inertia of the evolution of the built environment, such an orientation could, if consolidated, embody the promises of strong changes in future architectural productions.

The exhibition Habiter Mieux Habiter Plus, inaugurated in April 2018 in Paris, marks an architectural renewal in the production of Parisian housing. After four decades of formal festivities-inaugurated by the "Hautes-Formes complex and pursued by several generations of optimists defending architectural diversity-the architectural sobriety of the 63 projects presented in the exhibition is surprising. The residential architecture seems to be gradually recovering from the trauma of regularity. Architects are no longer afraid to repeat and align elements in the facades (Figure 7). Most of them express a homogeneous 'structure capable'.
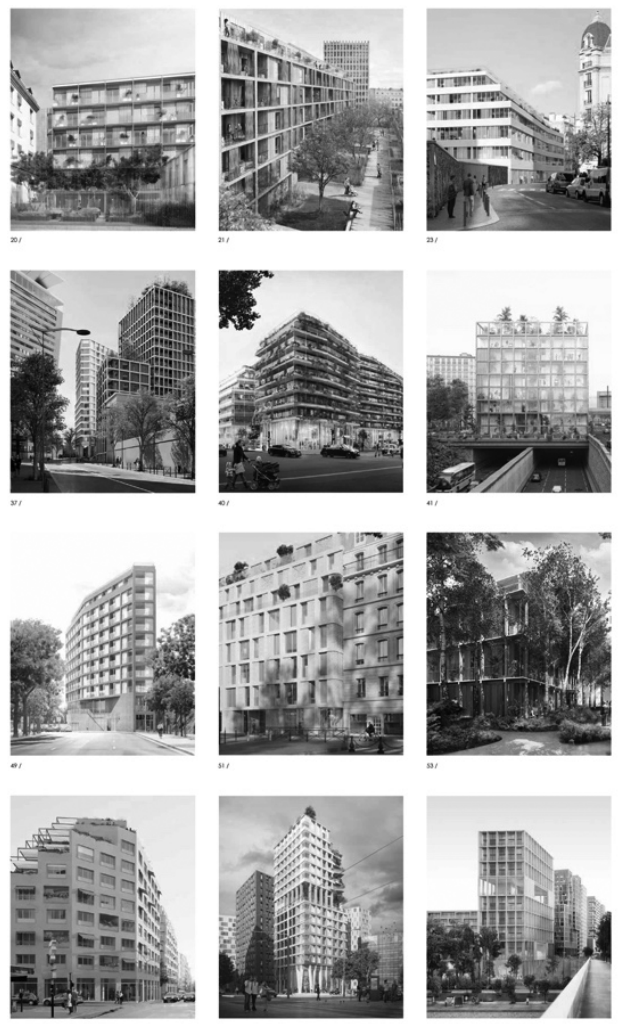
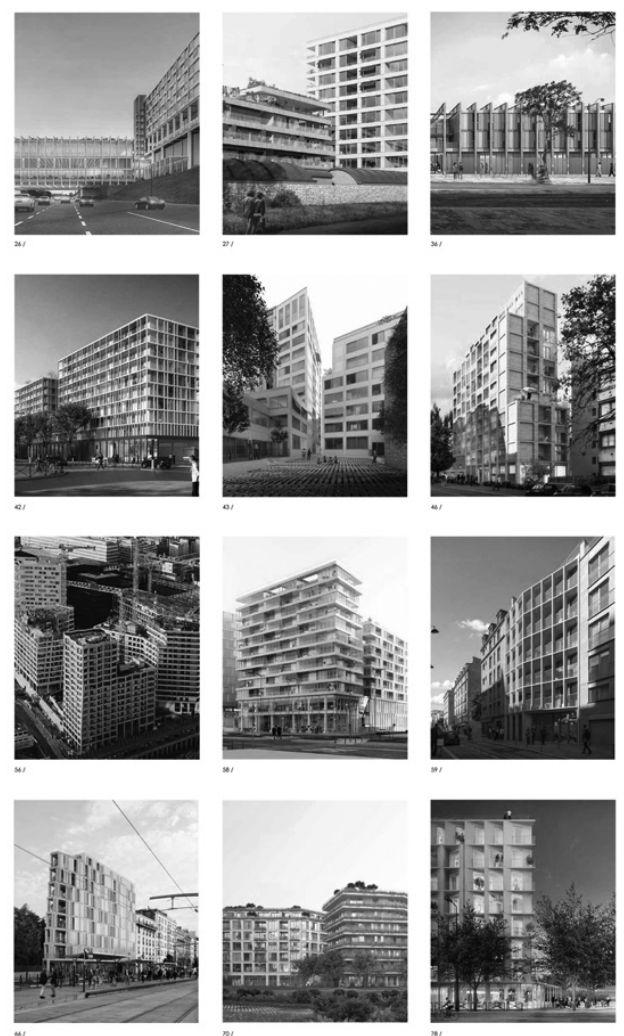
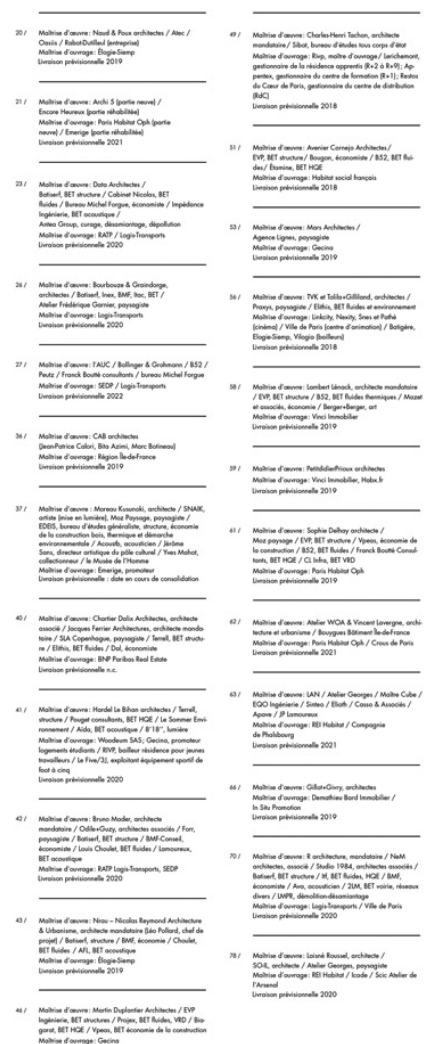

Figure 7. Extract from the press kit of the exhibition Habiter Mieux Habiter Plus presented at the Pavillon de l'Arsenal from April 5th to September 2nd of 2018. Source: Pavillon de l'Arsenal (2018). 
The majority of the projects presented tend to leave any domestic connotation out, even though they are collective housing. Like in the pioneering achievements of Lacaton and Vassal, only though the residents' appropriation of the houses though furniture can one perceive the nature of the interior program. The introduction of office standards to more domestic formalizations accentuates such undifferentiation. The same table or the same sofa are indifferently used in a living or in a meeting room. Even these supposedly distinctive secondary elements end up diluting programs within undifferentiated frames. The progression of home-office and co-working, the emancipation of the craft industry and, more generally, collaborative economy, digital economy, urban agriculture, or e-commerce, call for a redistribution of architectural connotations. These structural changes are accompanied by the construction of an architectural imaginary that the interior renderings of the competitions seek to make readable and attractive. The use of the vegetation on the upper floors only accentuates the perception of their homogeneity. The project designed by the architectural offices Jaspers-Eyers \& Partners, AUC and 51N4E for the renovation of WTC 1 and 2 Towers in Brussels adds further to the homogeneous city by fitting 127 dwellings between the floors of the Flemish administration headquarters (Figure 8). The project echoes the agility with which social networks seemingly connect companies, institutions and individuals. Behind the apparent homogeneity, a sophisticated distribution system addresses the programmatic characteristics of a public institution or that of a studio.

The disappearance of the boundaries associated with the traditional separation of urban functions-yet another component of the urban environment that the
CIAMs extended-could lead to the end of the corresponding categories, starting with "housing" (Landauer, 2013 , p. 34). The grand espace commun jeopardizes housing as an architectural program limited to the home, opening it up to wider and more diffuse perspectives. With the end of housing, its rebirth arrives, according to an updated interpretation of the habitat that Siegfried Giedon (1958, p. 202) had already anticipated: "The extended housing". If commercial and professional activities tend to dwindle in their urban forms, the "increased" housing - to emphase Giedon's words-could once again become a fundamental element as considered by the modern movement. Its contemporary formalization is actually similar to the constructive processes promoted during the second CIAM. In 1929, Le Corbusier summarizes the characteristics of housing for minimum incomes in these terms: "To act, human beings need horizontal well-lit surfaces, protected from the rain, temperature and curiosity. That's all!" (Steinmann, 1979, p. 62). The distinction he makes between "type of house" and "residential cell" when drawing up the program for the first CIAM (Steinmann, 1979, p. 18) anticipates the distinction between 'housing' and 'habitat' according to a respectively sterile and fruitful assessment of homogeneity. In its amplified form of "habitats cell" - to extend Le Corbusier's distinction-housing would once again become a major component of the construction of the city, according to an unexpected form of mono-functionalism: the same form regardless of the function, or the form that follows non-function. The exacerbated mix of functions until they can no longer be differentiated would paradoxically produce an astonishing surge of homogeneity. Once again, and more than ever, housing would build cities.
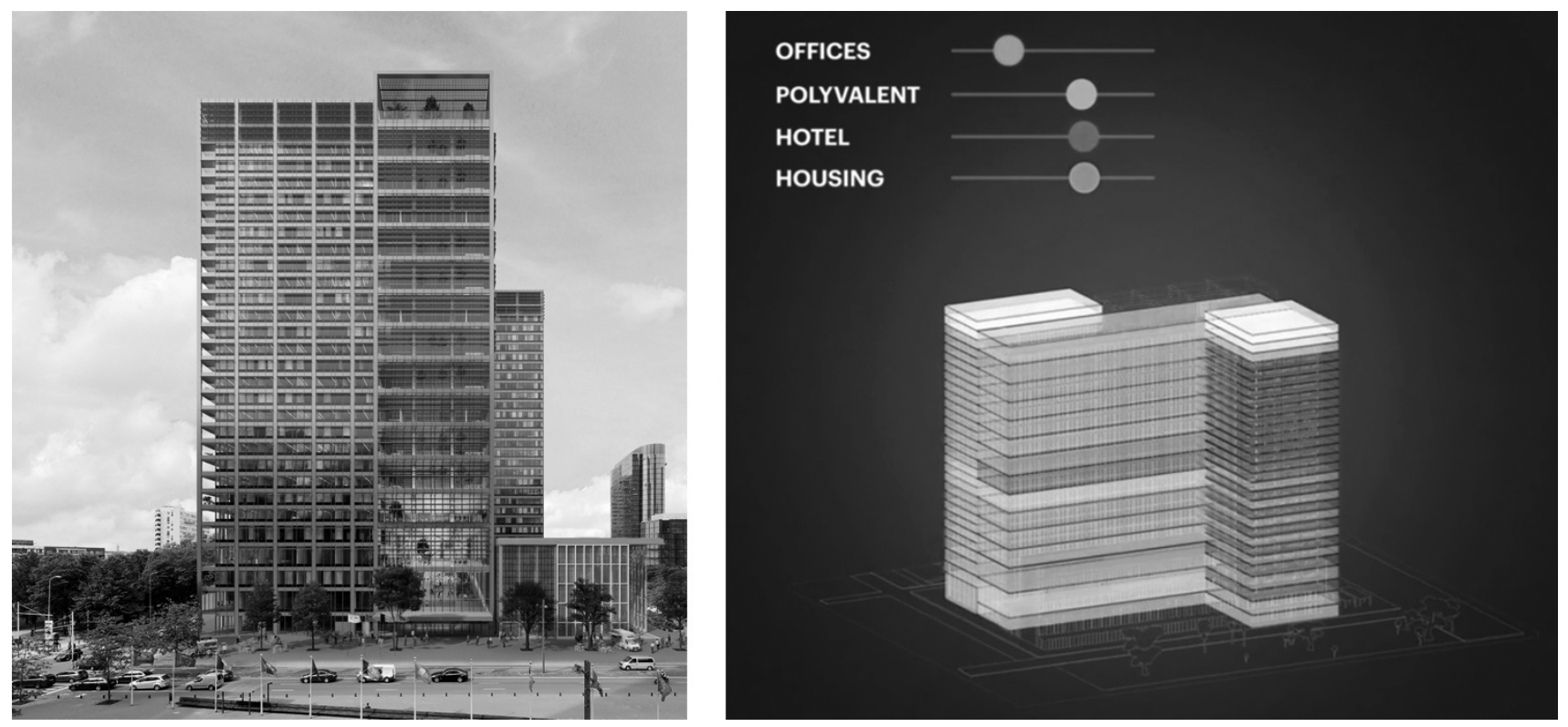

Figure 8. In 2023, the ZIN project will bring together housing, offices, a hotel, co-working spaces, sports areas, a food court and shops in a homogeneous architecture. Images courtesy of Befimmo, 51N4E, I'AUC and Jaspers-Eyers \& Partners, from the ZIN project competition, 2019, Brussels. 


\section{Conclusions}

The four periods examined reveal the possibility of considering urban homogeneity not only as the result of a progressive densification of the city (Castex, Depaule, \& Panerai, 2004, p. 180), but also as a voluntary and affirmative design principle. Its varied nature, evolving according to the context, can also be partial. Homogeneity does not need to be completed or generalized to become an urban principle. Alternatively associated with ordinary, vernacular or institutional construction, homogeneity has also accompanied the development of industrialization and mass society. On each of these occasions, homogeneity is mobilized in the field of a collective expression of habitat. Even the 'post-modern' reaction, exalting the creativity of architects in search of figurative originalities-whose collective scope still deserves to be measured-unintentionally contains an underlying homogeneity, even though it wanted to bring it to an end. A first answer to the title of the articledoes the homogeneous city belong to the past? - can be given by detaching urban homogeneity from the historical conditions of each period, and reading it as a sequential whole. The homogeneous city thus becomes a malleable and latent principle. Moreover, the principle of the homogeneous city, that has proven successful over the years, could be put at the service of new applications, in the face of the future architectural challenges. As the environmental crisis and climate changes inevitably mobilize a global scale of reflection, the deployment of effective solutions remains valid, complementary to local and diversified measures. The widespread use of external wall insulation has already oriented a large part of the new architectural production towards specific constructive and formal solutions. While the recent development of spectacular architectures has steered technical innovation away from the homogenization of built forms, technology and homogeneity could both find points of convergence in the future, provided that there is an adequate political and collective will. Future responses to urgent housing needs for the masses could benefit from leveraging the cumulative lessons of the homogeneous city. Outside these emergency contexts in which the acceptance of homogeneity is always facilitated, and closer to an ordinary and progressive trend, the evolution of the traditional categorization of 'housing' could have a significant impact on the contemporary approach of the homogeneous city. While the origins of habitat played a founding role in the emergence of this principle, the disappearance of housing as an object of planning and normative category could paradoxically become the terrain for the progressive rehabilitation, and architectural renewal, of the neglected qualities of homogeneity. The homogeneous city could then again be considered as a significant spatialized formalization of the living-together.

\section{Conflict of Interests}

The author declares no conflict of interests.

\section{References}

Alphand, A. (1867). Les promenades de Paris [The promenades of Paris]. Paris: Rothschild.

Aureli, P. V. (2013). The project of autonomy: Politics and architecture within and against capitalism. New York, NY: Buell Center, Forum Project Publications and Princeton Architectural Press.

Bailly, A. S., \& Beaudry, M. (1976). Analyse typologique en milieu urbain: Les aires homogènes d'Edmonton (Canada) [Urban typological analysis: Homogeneous areas in Edmonton (Canada)]. L'Espace géographique, 5(4), 267-276.

Baudelaire, C. (1868). Curiosités esthétiques [Aesthetic curiosities]. Paris: Michel Lévy Frères.

Castex, J., Depaule, J. C., \& Panerai, P. (2004). Formes urbaines: De l'îlot à la barre [Urban forms: The death and life of the urban block]. Marseille: Parenthèses.

Daly, C. (1864). L'architecture privée au XIX siècle [Private architecture in the 19th century]. Paris: Morel.

Daumier, H. (1847). Position réputée la plus commode pour avoir un joli portrait au daguerréotype [Position reputed most convenient to have a nice portrait in Daguerreotype]. [Lithography]. Cliché Bibliothèque Nationale de France (inv. Rés. Dc 180b). Bibliothèque Nationale de France, Paris, France.

Eleb, M. (1991). L'appartement de l'immeuble haussmannien [The apartment of the Haussmann building]. In P. Pinon \& J. Des Cars (Eds.), Paris-Haussmann (pp. 284-295). Paris: Picard.

Eleb, M., Cohen, J. L., \& Martinelli, A. (2000). Paris. Architecture 1900-2000. Paris: Norma.

Frampton, K. (1980). Modern architecture: A critical history. London: Oxford University Press.

Franzen, B. (1997). Neues Bauen der 20er jahre, Gropius, Haesler, Schwitters und die Dammerstocksiedlung in Karlsruhe 1929 [New building of the 20s, Gropius, Haesler, Schwitters and the Dammerstock settlement in Karlsruhe]. Karlsruhe: INFO.

French, H. (2008). Key urban housing of the twentieth century. London: Laurence King.

Garnier, C. (1892). L'habitation humaine [The human habitation]. Paris: Hachette.

Giedon, S. (1958). Architecture, you and me. Cambridge: Harvard University Press.

Gubler, J. (1988). Nationalisme et internationalisme dans l'architecture moderne de la Suisse [Nationalism and internationalism in Switzerland's modern architecture]. Geneva: Archigraphie.

Guiheux, A. (2017). Le grand espace commun, l'architecture transforme [The large common space, architecture transforms]. Geneva: MétisPresses.

Hilberseimer, L. (1927). Groszstadt architektur [Metropolis architecture]. Stuttgart: Hoffmann. 
International Kongresse für Neues Bauen. (1930). Die Wohnung für das Existenzminimum [Homes for minimum incomes]. Frankfurt am Main: Englert \& Schlosser.

Landauer, P. (2013). La fin du logement [The end of housing]. In F. Lenne (Ed.), Habiter. Imaginons l'évidence! [Living. Imagine the obvious!] (pp. 34-37). Paris: Carré.

Loyer, F. (1987). Paris XIX siècle: L'immeuble et la rue [Paris 19th century: The building and the street]. Paris: Hazan.

Lucan, J. (1992). Eau et gaz à tous les étages: Paris, 100 ans de logements [Gas and water on every floor: Paris, 100 years of housing]. Paris: Pavillon de l'Arsenal.

Lucan, J. (2012). Où va la ville aujourd'hui? Formes urbaines et mixités [Where is the city going today? Urban forms and mixes]. Paris: La Villette.

Maïzia, M. (1999). Contribution théorique à la mesure de l'homogénéité des tissus urbains [Theoretical contribution to the measurement of the homogeneity of urban fabrics]. Cybergeo: European Journal of Geography. http://dx.doi.org/10.4000/cybergeo.5079

Mohr, C. (2011). Typisierung im wohnungsbauDas Frankfurter beispiel [Typology in residential construction-The Frankfurt example]. In H. Barr (Ed.), Neues wohnen 1929/2009 [New living 1929/2009] (pp. 54-67). Berlin: Jovis.

Paris. Avenue de l'Opéra, percement et projets. (1876). [Engraving]. Recueil iconographique (1-EST-00464). Bibliothèque Historique de la Ville de Paris, Paris, France.

Paris, rue des Hautes-Formes. Dossier iconographique (1979). [Photography]. Recueil iconographique (1EST-02448). Bibliothèque Historique de la Ville de Paris, Paris, France.

Pavillon de I'Arsenal. (2018). Exposition Habiter Mieux
Habiter Plus dossier de presse. 04/09 2018. Pavillon de l'Arsenal [Exhibition "Living Better Living More" press kit. April/September 2018. Arsenal Pavillon]. Paris: Pavillon de l'Arsenal.

Périphériques Architectes. (2007). Autrement rue Rebière [Otherwise Rebière Street]. Paris: Éditions du Pavillon de l'Arsenal.

Porotto, A. (2018). Logement de masse: Vienne et Francfort [Mass housing: Vienna and Frankfurt] (Unpublished Doctoral dissertation). Lausanne: Swiss Federal Institute of Technology Lausanne. http://dx.doi. org/10.5075/epfl-thesis-8736

Portzamparc, C. (1984). Christian de Portzamparc. Paris: Electra Moniteur.

Pushwagner, H. (2017). Soft-city. Paris: Dernière marge.

Quatremère de Quincy, A. C. (1788-1825). Encyclopédie méthodique. Architecture [Methodical encyclopedia. Architecture]. Paris: Panckoucke.

Rossi, A. (1966). L'architettura della città [The architecture of the city]. Padova: Marsilio.

Rossi, A., Consolascio, E., \& Bosshard, M. (1979). La costruzione del territorio del Cantone Ticino [The construction of the territory of the Canton Ticino]. Lugano: Fondazione Ticino Nostro.

Steinmann, M. (1979). CIAM: Internationale kongresse für neues bauen. Dokumente 1928-1939 [CIAM: International congresses for modern architecture. Documents 1928-1939]. Basel: Birkhäuser.

Viollet-le-Duc, E. (1872). Entretiens sur l'architecture [Interviews on architecture]. Paris: Morel.

Vitruvius (1673). Les dix livres d'architecture de Vitruve [The ten architecture books of Vitruvius]. Paris: Coigna.

Wagner, M. (1979). Untitled. [Photography]. Siedlung Blumläger Feld (StadtA CE). City Archive Celle, Celle, Germany.

\section{About the Author}

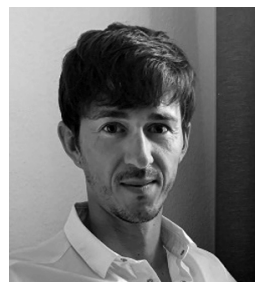

Valentin Bourdon is an Architect, graduated from the Eav\&t Paris-Est in 2013, and PhD student at the Laboratory of Construction and Conservation (LCC) EPFL since 2017. His actual research explores the architectural challenges of the common space. In support of significant historical experiences, and contemporary subjects, such a project aims to help overcome the delay taken by architecture comparing to other disciplines in the appropriation of the notion of 'common'. 